AGRICULTURE AND BIOLOGY JOURNAL OF NORTH AMERICA

ISSN Print: 2151-7517, ISSN Online: 2151-7525, doi:10.5251/abjna.2013.4.1.67.70

(C) 2013, ScienceHu $\beta$, http://www.scihub.org/ABJNA

\title{
Prevalence of cestode parasites in free-range backyard chickens (Gallus gallus domestics) of Kashmir, India
}

\author{
Javid Ahmad Dar and Syed Tanveer \\ Department of Zoology, University of Kashmir, Srinagar-190 006 \\ Corresponding author's e-mail:javid60@gmail.com
}

\begin{abstract}
The present study was carried out on free-range backyard chicken (Gallus gallus domesticus) from April 2011 to March 2012 (10 hosts per month) to determine the prevalence, mean intensity and species diversity of cestode parasites of domestic fowl in Kashmir valley, northwest Himalayan region of India. Of the total 120 (50 male and 70 female) chickens collected from different localities of Kashmir , 103 (85.83 \%) were found infected with cestode parasites. In this survey nine cestode parasites belonging to four genera were recovered from the gastrointestinal tract of infected chickens. The cestode species and their prevalence were: Raillietina tetragona (65\%), R. cesticillus (22.50\%), R. echinobothrida (33.33\%), R. spiralis (26.66\%), Choanotaenia infundibulum (18.33\%), C. gondwana (10.83\%), Amoebotaenia cuneata (20.00\%), A. domesticus (15.00\%), Davainea proglottina (18.33\%).
\end{abstract}

Key words: Cestode; Prevalence; Intensity; Gallus gallus domesticus; Free-range backyard;Kashmir

\section{INTRODUCTION}

Domestic fowl is reared in most parts of the world either in the backyard or commercial production system. Poultry products form one of the most important sources of protein for man. Like other parts of the world, poultry production is an important area of agriculture practice in Kashmir valley. Domestic fowl (Gallus gallus domesticus) is one of the most common and widespread domestic animal that acts as the source of meat, eggs, feathers and organic manure of high fertility. This biotic resource is means of income for many sections of Kashmiri population. Poultry production has emerged as check and balance on the rising prices of mutton in the valley. However, parasitism presents a main threat to the indigenous poultry production and cause heavy economic losses in the production of meat and eggs. Helminthosis is considered one of the most common diseases that affect free-range backyard chickens (Soulsby, 1982 ; Permin et al., 1997). Even severe cases of parasitism can cause mortality of infected birds (Soulsby, 1982). The domestic fowl infected with cestodes show retarded growth, decreased egg production, reduced weight gain and significant haemoglobin depression (Nair and Nadakal ,1981). Cestode infected chickens also show villous atrophy, catarrhal enteritis, granuloma formation in duodenum, desquousmation of villi and submocousal glands congestion, inflammatory reaction and vacoulation of epithelial cells (Kurkure et al, 1998).
Little work is available on the cestode parasites of domestic fowl in Kashmir valley (Fotedar and Khateeb,1987; Pandit et al.1999 and Salam et al. 2010 ) when compared to similar work done in other parts of our country and rest of the World. The present work was therefore aimed to investigate the prevalence, mean intensity and the species diversity of cestode parasites in the free range backyard chicken (Gallus gallus domesticus) in Kashmir valley, India. The results of this study may prove helpful for the future research on these cestodes from this region.

\section{MATERIALS AND METHODS}

Study area: Kashmir valley is a temperate nort west Himalayan region of Jammu and Kashmir State inlndia. It lies between $33^{\circ} 20^{\prime}$ and $34^{\circ} 54^{\prime} \mathrm{N}$ latitudes and $73^{\circ} 55^{\prime}$ and $75^{\circ} 35^{\prime} \mathrm{E}$ longitudes, covering an area of about $15,948 \mathrm{sq} \mathrm{km}$. It is a deep bowl shaped valley bounded by lofty mountains of the Pir Panjal range in the south and south west and the great Himalayan range in the north and east. The floristic and faunal diversity of the valley is considerably rich owing to its unique topography, temperate climate and geographical isolation from the surrounding plains (Dar et al., 2002). Majority of the people practice agriculture and live stock husbandry is an important source of income.

Collection and processing of cestodes: The present investigation for cestode parasites was done 
on 120 chickens during the study period of twelve months from April 2011 to March 2012 (10 hosts per month). The chickens were randomly purchased from different localities of Kashmir valley either directly from the farmers or from local poultry bird sellers. The collected chickens were brought to the Parasitology Research Laboratory, Department of Zoology, University of Kashmir. The intestines were slit open by longitudinal incision from duodenum to cloaca including both ceacal tubes. The parasites, if any, were removed by brush and fine forceps and washed in normal saline. Cestodes were fixed in Cornoy's fixative, stained in Acetoalum carmine and transferred to xylene for clearing before mounting them in DPX (Dextrine Plasticised Xylene).The drawings of the specimens were made with the help of prism type camera lucida. Measurements were taken with objective and stage micrometers and expressed in $\mathrm{mm}$. The specimens were identified using Soulsby (1982) and Yamaguti (1961). The prevalence and mean intensity was obtained following nomenclature given by Bush et al. (1997).

\section{RESULTS}

Table 1 Prevalence of Cestode infections in different age and sex groups in free-range backyard chickens

\begin{tabular}{|l|c|c|c|c|c|c|}
\hline \multirow{2}{*}{ Age group } & \multicolumn{2}{|c|}{ No. of chickens examined } & \multirow{2}{*}{$\begin{array}{c}\text { Total no. } \\
\text { examined }\end{array}$} & \multicolumn{2}{|c|}{ No. of infected chickens(\%) } & Infection (\%) \\
\cline { 2 - 3 } & Male & Female & & Male & Female & \\
\hline Adults & 37 & 57 & 94 & $33(89.18)$ & $50(87.71)$ & $83(88.29)$ \\
\hline Nestlings & 13 & 13 & 26 & $10(76.92)$ & $10(76.92)$ & $20(76.92)$ \\
\hline Total & 50 & 70 & 120 & $43(86)$ & $60(85.71)$ & $103(85.83)$ \\
\hline
\end{tabular}

Table 2 Prevalence and intensity of cestode parasites in 120 free-range backyard chickens from Kashmir

\begin{tabular}{|l|c|c|c|c|c|}
\hline Cestode species & $\begin{array}{c}\text { No. of infected } \\
\text { chickens }\end{array}$ & $\begin{array}{c}\text { No. of cestode } \\
\text { parasites }\end{array}$ & $\begin{array}{c}\text { Mean } \\
\text { intensity }\end{array}$ & $\begin{array}{c}\text { Range } \\
\text { (\%) }\end{array}$ & \\
\hline Raillietina tetragona & 78 & 229 & 2.93 & $1-5$ & 65.00 \\
\hline R. cesticillus & 27 & 78 & 2.88 & $1-4$ & 22.50 \\
\hline R. echinobothrida & 40 & 93 & 3.32 & $2-3$ & 33.33 \\
\hline R.spiralis & 32 & 50 & 1.56 & $1-3$ & 26.66 \\
\hline Choanotaenia infundibulum & 22 & 42 & 1.90 & $1-5$ & 18.33 \\
\hline C.gondwana & 13 & 43 & 3.30 & $2-3$ & 10.83 \\
\hline Amoebotaenia cuneata & 24 & 58 & 2.41 & $1-4$ & 20.00 \\
\hline A. domesticus & 18 & 52 & 2.88 & $1-6$ & 15.00 \\
\hline Davainea proglottina & 22 & 95 & 4.31 & $1-8$ & 18.33 \\
\hline
\end{tabular}




\section{DISCUSSION}

The overall prevalence rate of different cestode parasites in free-range backyard chickens was considerably high, reflecting that the cestode infection is a common problem in the study area.The observed mean intensity of worms in the alimentary canal of infected birds might be due to consumption of infested droppings or infested intermediate hosts of parasites such as beetles, cockroaches, earthworms, flies and grasshoppers in poorly managed stocks (Abdu,1987). However, high prevalence of cestodes in nestlings suggests that infections generally occurred at early ages (Radfar et al., 2012). The high prevalence of Raillietina species may be ascribed to the easy accessibility of intermediate hosts (dung beetles, ants) to the free range backyard chickens in the study area. The nodule formation induced by $R$. echinobothrida may lead to confusion with lesions of avian tuberculosis (Ahenafi and Eshetu 2004). Cestode infection in poultry are known to cause retarded growth, diarrhea, enteritis, haemorrhages and hypovitaminosis B. In addition to these deleterious effects, heavy infections may also lead to mortality in young birds and lowering or loss of egg production in laying chickens (Layers). The most prevalent cestode parasite during the present study was $R$. tetragona. Seventy eight out of 120 chickens were infected with $R$. tetragona $(65 \%)$, with intensities ranged from 1 to 5 and mean intensity of 2.93 (Table 2). The high prevalence of $R$. tetragona may be attributed to the availability of sufficient number of intermediate hosts (ants) and favourable environmental conditions for the completion of its life cycle. The prevalence of $R$. cesticillus was $22.5 \%$ which is consistent with the prevalence of the same parasite reported earlier from this region (Salam et al, 2010).

The current study indicates that free range chickens are considered as potential reservoirs for cestode infections and thus pose a risk of contamination to modern commercial poultry farms. Therefore, further investigation is imperative to elucidate the economic and hygiene impacts of parasitic infections in general and cestode infections in particular, on free range backyard poultry birds. The present study also suggests that nestlings must not be kept in close proximity of older chickens as the latter often act as a reservoir of infection for the former.

\section{ACKNOWLEDGMENTS}

The authors express their deep sense of gratitude and sincere thanks to Prof. M. Z. Chishti, Professor

Emeritus, Centre of Research for Development (CORD), University of Kashmir, for helping in the identification of cestode parasites recovered during the study.

\section{REFERENCES}

Abdu PA (1987) Infectious bursal disease in pullet chicks. Avian Dis 31:204-205.

Ashenafi H, Eshetu $Y$ (2004) Study on gastrointestinal helminths of local chickens in central Ethiopia. Rev Med Vet 155:504-507.

Bush, A. O., Lafferty, K. D., Lotz, J. M. and Shostok, W. (1997) Parasitology meets ecology on its own terms. J. Parasitol., 83(4): 575-583.

Dar, GH, Bhagat, RC and Khan M A, 2002. Biodiversity of the Kashmir Himalaya, Ist Edn. Valley Book House, Kashmir University Road, Srinagar-190006 (India).ISBN 81-86592-12-1.

Fotedar, D. N., N. G. Khateeb (1986) Occurrence and seasonal variation of helminth parasites of domestic fowl in Kashmir.Indian J. Helminthol. 38, 49-54.

Eshetu Y, Mulualem E, Ibrahim H, Berhanu A, Aberra K (2001) Study of gastro-intestinal helminths of scavenging chickens in four rural districts of Amhara region, Ethiopia. Rev Sci Tech Oie 20:791-796.

Ganaie, N. A., A. A. Khan, M. S. Mir, G. A. Bhat (2004) Effect of Levamisol on endoparasitic infestation of fowls in Kashmir valley. The Blue Cross Book 22, 2425.

Hassouni, T., D. Belghyti (2006) Distribution of gastrointestinal helminths in chicken farms in the Gharb region - Morocco. Parasitol. Res. 99, 181-183.

Kurkure,N.V.,S.W Kolte, A.G Ganorkar, A.G Bhandarkar (1998) Raillietina cesticillus in Pigeon (Columbia livia).Indian Vertinary Journal. 75:835-836.

Nair,K.V., A.M Nadakal,(1981) Hematological changes in domestic fowl infected with cestode Raillietina tetragona(Molin,1958).Vertinary Parasitology.8:4958.

Pandit, B. A., A. S. Mir, M. A. A. banday, R. A. Shahardar (1991) Prevalence of helminth parasites in Indigenous fowls of Kashmir Valley. Poult. Adv. $\mathrm{XXIV}(\mathrm{X})$, 37-39.

Permin ,A., Magwisha, H., Kassuku, A. A., Nansen, P., Bisgaard, M., Frandsen, F., Gibbons, L., (1997) A cross- sectional study of helminths in rural scavenging poultry in Tanzania in relation to season and climate. J. Helminthol. 71,233-240. 
Radfar MH, Norouzi Asl E, Rezaei Seghinsara H, Mirzaei Dehaghi M, Fathi S (2012) Biodiversity and prevalence of parasites of224 J Parasit Dis (July-Dec 2012) 36(2):220-225.

Salam, S. T., M. S. Mir, A. R. Khan (2010) The prevalence and pathology of Raillietina cesticillus in indigenous chicken (Gallus gallus domesticus) in the temperate Himalayan region of Kashmir. Veterinarski Arhiv 80 (2), 323-328.

SSoulsby, E. J. L. (1982) Helminths, Arthropods and Protozoa of Domesticated animals. $7^{\text {th }}$ ed., Bailliere Tindall, London, UK. 